\title{
MELANOSTATIN, A NEW MELANIN SYNTHESIS INHIBITOR \\ PRODUCTION, ISOLATION, CHEMICAL PROPERTIES, STRUCTURE AND BIOLOGICAL ACTIVITY
}

\author{
Yasumasa Ishihara, Masahisa OKa, Mitsuaki Tsunakawa, Koji Tomita, \\ Masami Hatori, Haruaki Yamamoto, Hideo Kamei, Takeo MiYaki, \\ Masataka Konishi and ToshikazU OKI \\ Bristol-Myers Squibb Research Institute, \\ 2-9-3 Shimo-meguro, Meguro-ku, Tokyo 153, Japan \\ (Received for publication July 14, 1990)
}

\begin{abstract}
Melanostatin, a new antibiotic with melanin synthesis inhibitory activity, was isolated from the fermentation broth of Streptomyces clavifer No. N924-2. Its structure was determined by spectral analysis and degradation experiments. Melanostatin strongly inhibited melanin formation in Streptomyces bikiniensis NRRL B-1049 and B16 melanoma cells.
\end{abstract}

In a previous paper ${ }^{1)}$, we reported a screening method for melanin synthesis inhibitors among microbial metabolites and the isolation of several known active substances obtained from such screening.

In our continuing search for the active metabolites, a microbial organism isolated from a soil sample collected in Greece was found to produce an active compound designated melanostatin. Taxonomical study showed that the producing organism, strain N924-2 was Streptomyces clavifer. The active principle in the fermentation broth was isolated by use of ion exchange and gel permeation chromatography. Structural studies revealed that melanostatin is a novel pseudotripeptide with a molecular formula of $\mathrm{C}_{19} \mathrm{H}_{25} \mathrm{~N}_{5} \mathrm{O}_{5}$ and is structurally related to feldamycin ${ }^{2)}$ and FR-900,490 ${ }^{3)}$. Melanostatin inhibited melanin formation in Streptomyces bikiniensis NRRL B-1049 and B16 melanoma cells but did not show inhibitory activity against mushroom tyrosinase. This paper presents the taxonomy of the producing strain No. N924-2 and the fermentation, isolation, structure and biological activity of melanostatin.

\section{Taxonomy}

Strain N924-2 was isolated from a soil sample collected in Greece.

\section{Morphology}

Strain N924-2 forms branching hyphae $(0.5 \mu \mathrm{m}$ in width), which develop into substrate and aerial mycelia. Both mycelia are well-branched and non-fragmentary. The aerial hyphae are monopodially branched, and bear long straight spore chains. The spore chains contain 10 to 50 or more spores in a chain. The spores are rectangular in shape, $0.4 \sim 0.5 \times 0.6 \sim 0.8 \mu \mathrm{m}$ in size, with a smooth surface (Fig. 1). Sclerotium, sporangium and motile spores are not observed.

\section{Cultural and Physiological Characteristics}

The sporulated aerial mycelia are white to yellow. The color of substrate mycelia is colorless or moderate yellow to light olive brown. No distinct pigments are produced. Tyrosinase reaction is negative. Gelatin and starch are hydrolyzed. The $\mathrm{NaCl}$ tolerance is seen at $9 \%$. The growth range is from $12^{\circ} \mathrm{C}$ to 
Fig. 1. Scanning electron micrographs showing straight spore chains of strain N924-2.

(A) Medium: Inorganic salts-starch agar (ISP medium No. 4). Cultivation: $28^{\circ} \mathrm{C}$ for 14 days. (B) Medium: Yeast extract-malt extract agar (ISP medium No. 2). Cultivation: $28^{\circ} \mathrm{C}$ for 21 days.

(A)

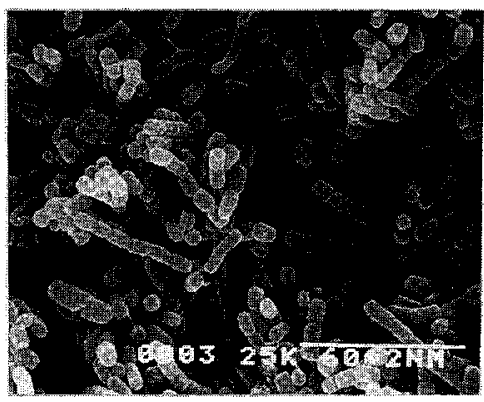

(B)

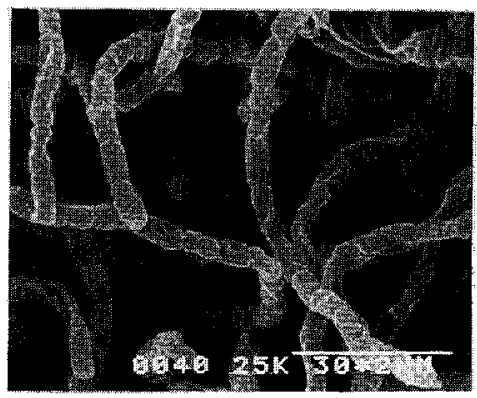

Table 1. Cultural characteristics of strain N924-2.

\begin{tabular}{|c|c|c|c|c|}
\hline Medium & Growth & Aerial mycelium & Substrate mycelium & Diffusible pigment \\
\hline $\begin{array}{l}\text { Sucrose - nitrate agar } \\
\text { (CZAPEK - Dox agar) }\end{array}$ & Poor & Poor; white (263) & Colorless & None \\
\hline $\begin{array}{l}\text { Tryptone - yeast extract } \\
\text { broth (ISP No. 1) }\end{array}$ & $\begin{array}{l}\text { Moderate; } \\
\text { not turbid }\end{array}$ & None & Colorless & None \\
\hline $\begin{array}{l}\text { Yeast extract - malt } \\
\quad \text { extract agar (ISP No. 2) }\end{array}$ & Good & $\begin{array}{l}\text { Abundant; } \\
\text { yellowish white (92) }\end{array}$ & $\begin{array}{l}\text { Light olive } \\
\text { brown (94) }\end{array}$ & $\begin{array}{l}\text { Moderate yellowish } \\
\text { brown (77) }\end{array}$ \\
\hline $\begin{array}{l}\text { Oatmeal agar } \\
\text { (ISP No. 3) }\end{array}$ & Moderate & $\begin{array}{l}\text { Moderate; } \\
\text { yellowish white (92) }\end{array}$ & Colorless & None \\
\hline $\begin{array}{l}\text { Inorganic salts - starch } \\
\text { agar (ISP No. 4) }\end{array}$ & Good & $\begin{array}{l}\text { Abundant; } \\
\text { white to yellowish } \\
\text { white }(92)\end{array}$ & Moderate yellow (87) & None \\
\hline $\begin{array}{l}\text { Glycerol - asparagine } \\
\text { agar (ISP No. 5) }\end{array}$ & Good & $\begin{array}{l}\text { Abundant; } \\
\text { yellowish white }(92)\end{array}$ & Pale yellow (89) & None \\
\hline $\begin{array}{l}\text { Peptone - yeast extract - } \\
\text { iron agar (ISP No. 6) }\end{array}$ & Moderate & $\begin{array}{l}\text { None or scant; } \\
\text { white }(263)\end{array}$ & Colorless & None \\
\hline $\begin{array}{r}\text { Tyrosine agar } \\
\text { (ISP No. 7) }\end{array}$ & Moderate & $\begin{array}{l}\text { Moderate; } \\
\text { yellowish white }(92)\end{array}$ & Colorless & None \\
\hline $\begin{array}{l}\text { Glucose - asparagine } \\
\text { agar }\end{array}$ & Moderate & $\begin{array}{l}\text { Poor; } \\
\quad \text { yellowish white (92) }\end{array}$ & Colorless & None \\
\hline BENNETT's agar & Moderate & $\begin{array}{l}\text { Moderate; } \\
\text { yellowish white (92) }\end{array}$ & Moderate yellow (87) & None \\
\hline
\end{tabular}

Observations after incubation at $28^{\circ} \mathrm{C}$ for 3 weeks.

Color and number in parenthesis follow ISCC-NBS designation.

$35^{\circ} \mathrm{C}$ with no growth observed at $37^{\circ} \mathrm{C}$. Among eleven sugars described in BERGEY's Manual ${ }^{4)}$, D-glucose, D-xylose, L-rhamnose, D-fructose, D-galactose, D-mannitol, salicin and sucrose are utilized for growth, whereas L-arabinose, raffinose and inositol are not utilized. The cultural characteristics are shown in Table 1.

\section{Chemotaxonomy}

The whole-cell hydrolysate contains the LL-isomer of diaminopimelic acid and no diagnostic sugar.

\section{Taxonomic Position}

The above-mentioned characteristics of strain N924-2 revealed that it belongs to the genus 
Streptomyces. According to the descriptions of the genus Streptomyces by PRIDHAM and TRESNER ${ }^{4)}$, the major characteristics of strain N924-2 are summarized as follows: 1) aerial mycelium, white (W) or yellow $(\mathrm{Y}), 2)$ spore chain, Rectus-Flexibilis (RF), 3) chromogenicity, negative (C-), and 4) spore ornamentation, smooth (SM). This type of Streptomyces species is shown in Table 17.41b (W, RF, C-, SM) and Table 17.43b (Y, RF, C-, SM) of BERGEY's Manual, which include 7 species and 46 species, respectively. The morphological, cultural and physiological characteristics of strain N924-2 were compared to the descriptions of 53 species by Pridham and Tresner ${ }^{4)}$, Shirling and GottlieB ${ }^{5 \sim 8)}$, and WaKSMAN ${ }^{9)}$. Strain N924-2 resembles S. clavifer (Millard and Burr) Waksman 1953, and Streptomyces lipmanii (Waksman and Curtis) Waksman and Henrici 1948 in the formation of long spore chain of Rectus-Flexibilis, the absence of distinct pigment formation and the profile of sugar utilization. It is a little different from S. clavifer in the absence of brick-red substrate mycelium in CZAPEK's sucrose - nitrate agar, and from S. lipmanii in the predominant formation of flexuous spore chain of the latter. However, it forms a club-shaped structure at the tip of the straight spore chain similar to that of $S$. clavifer in CZAPEK's agar. Therefore, strain N924-2 is classified as $S$. clavifer based on the spore chain morphology.

\section{Fermentation}

A stock culture of $S$. clavifer strain N924-2 was propagated on an agar slant (ISP No.4) having the composition of soluble starch $1 \%, \mathrm{~K}_{2} \mathrm{HPO}_{4} 0.1 \%, \mathrm{MgSO}_{4} \cdot 7 \mathrm{H}_{2} \mathrm{O} 0.1 \%, \mathrm{NaCl} 0.1 \%,\left(\mathrm{NH}_{4}\right)_{2} \mathrm{SO}_{4} 0.2 \%$, $\mathrm{CaCO}_{3}, 0.2 \%$ and agar $2 \%$ at $28^{\circ} \mathrm{C}$ for 7 days. The mature agar slant was used to inoculate a $500-\mathrm{ml}$ Erlenmeyer flask containing $100 \mathrm{ml}$ of seed medium composed of glucose $2 \%$, fish meal $1 \%$ and $\mathrm{CaCO}_{3}$ $0.5 \%$ (the $\mathrm{pH}$ being adjusted to 7.0 before sterilization). The flask was then incubated at $28^{\circ} \mathrm{C}$ for 3 days on a rotary shaker $(200 \mathrm{rpm})$ and $5 \mathrm{ml}$ portions of the growth were transferred into $500-\mathrm{ml}$ Erlenmeyer flasks containing $100 \mathrm{ml}$ of production medium with the same composition as the seed medium. The fermentation was carried out at $28^{\circ} \mathrm{C}$ for 8 days using a rotary shaker.

Melanin synthesis inhibitory activity was determined by the paper-disc agar diffusion assay method using $S$. bikiniensis NRRL B-1049 as the test organism ${ }^{1)}$. A large scale fermentation was carried out in stainless steel fermenters. The seed culture prepared in twenty $500-\mathrm{ml}$ Erlenmeyer flasks was poured into a 200-liter stainless tank containing 120 liters of the production medium described above. The fermentation was run at $28^{\circ} \mathrm{C}$ for 8 days with stirring at $250 \mathrm{rpm}$ and aerating at 120 liters/minute. The activity of melanostatin reached a maximum of $50 \mu \mathrm{g} / \mathrm{ml}$ after 6 to 7 days fermentation.

\section{Extraction and Purification}

The fermentation broth (200 liters, $\mathrm{pH} 8.3$ ) was centrifuged with the aid of a Sharples-type centrifuge (Kokusan No. 6). The broth filtrate was adjusted to $\mathrm{pH} 7.3$ with $6 \mathrm{~N} \mathrm{HCl}$ and stirred for 1 hour with active carbon (Takeda, Shirasagi KLH-250, $2.5 \mathrm{~kg}$ ) to adsorb the activity. The charcoal was collected by filtration, washed with water ( 25 liters) and eluted with $80 \%$ aqueous acetone ( 20 liters). The eluate was concentrated to an aqueous solution (1 liter) which was subjected to column chromatography on Amberlite IRC-50 $\left(\mathrm{H}^{+}\right.$form, 1 liter) developed with water (1.5 liters) and then with $2 \mathrm{~N} \mathrm{NH}_{4} \mathrm{OH}$ (1.1 liters). Concentration of the aqueous ammonia eluate yielded $18 \mathrm{~g}$ of brown solid. This was chromatographed on a silica gel column (Merck-Darmstadt Art No. 9385, $820 \mathrm{ml}$ ) using dichloromethane- EtOH - 14\% $\mathrm{NH}_{4} \mathrm{OH}(9: 14: 3$ ) as eluant. The eluate was monitored for melanin synthesis inhibitory activity by the paper-disc assay against $S$. bikiniensis NRRL B-10491). The active fractions were combined and concentrated to dryness in vacuo to give $930 \mathrm{mg}$ of yellow solid. This solid was purified on a silica gel column $(880 \mathrm{ml})$ eluted 
with $\mathrm{BuOH}-\mathrm{AcOH}$ - water $(4: 1: 1)$. The fractions containing melanostatin were detected by the bioassay and also by TLC $\left(\mathrm{SiO}_{2}, \mathrm{BuOH}-\mathrm{AcOH}\right.$ - water $(3: 1: 2)$, iodine detection). Melanostatin showed a brown spot at $\mathrm{Rf}$ 0.19. The appropriate fractions were concentrated in vacuo and the residue was re-chromatographed on a silica gel column $(270 \mathrm{ml})$ using the same solvent system as above. Evaporation of the active fractions yielded melanostatin as a nearly homogeneous solid ( $300 \mathrm{mg}$ ) which was subjected to Sephadex LH-20 chromatography $(880 \mathrm{ml})$ for complete desalting. Elution was carried out with $50 \%$ aqueous methanol and the active eluate was concentrated to yield $220 \mathrm{mg}$ of pure melanostatin.

\section{Physico-chemical Properties}

Melanostatin was isolated as a white amorphous solid. It was readily soluble in water, methanol and ethanol, slightly soluble in dimethyl sulfoxide and insoluble in acetone, dichloromethane, chloroform and ethyl acetate. It gave yellowish brown and dark gray color reactions after spraying with iodine and sulfuric acid, respectively, on TLC plates. Melanostatin was weakly positive to ninhydrin reaction but was negative to Sakaguchi and anthrone reactions. The antibiotic was assigned a molecular formula of $\mathrm{C}_{19} \mathrm{H}_{25} \mathrm{~N}_{5} \mathrm{O}_{5}$ based on the HRFAB mass spectrum and ${ }^{13} \mathrm{C}$ NMR spectrum (19 carbon signals). Table 2 summarizes the physico-chemical properties of melanostatin. The UV spectrum of melanostatin did not show a maximum above $210 \mathrm{~nm}$ and its IR spectrum (Fig. 2) showed broad absorption at around 3300 3100 $\mathrm{cm}^{-1}(\mathrm{OH}$ or $\mathrm{NH})$ and carbonyl absorptions at $1670 \sim 1620 \mathrm{~cm}^{-1}$. The ${ }^{1} \mathrm{H}$ NMR spectrum in $\mathrm{D}_{2} \mathrm{O}$ $(400 \mathrm{MHz})$ is illustrated in Fig. 3.

\section{Structural Studies}

The physico-chemical and spectral properties stated above resemble those of feldamycin ${ }^{2 y}$ and FR-900,490 $0^{3)}$ which were found to have melanin

Table 2. Physico-chemical properties of melanostatin.

\begin{tabular}{ll}
\hline Nature & White amorphous powder \\
MP & Gradually dec over $155^{\circ} \mathrm{C}$ \\
{$[\alpha]_{D}^{29}$} & $+50^{\circ}\left(c 1.0, \mathrm{H}_{2} \mathrm{O}\right)$ \\
& $+34^{\circ}(c 1.0,0.1 \mathrm{~N} \mathrm{HCl})$ \\
Molecular formula & $\mathrm{C}_{19} \mathrm{H}_{25} \mathrm{~N}_{5} \mathrm{O}_{5}$ \\
HRFAB-MS $(m / z)$ & Obsd: $404.1941\left(\mathrm{MH}^{+}\right)$ \\
& Calcd for $\mathrm{C}_{19} \mathrm{H}_{26} \mathrm{~N}_{5} \mathrm{O}_{5}: 404.1933$ \\
$\mathrm{UV}\left(\mathrm{H}_{2} \mathrm{O}\right)$ & End absorption \\
IR $(\mathrm{KBr}) \mathrm{cm}^{-1}$ & $3300 \sim 3100,1670(\mathrm{sh}), 1620,1390$ \\
TLC, SiO & Rf $0.29^{\mathrm{a}}$ \\
& Rf $0.19^{\mathrm{b}}$ \\
\hline
\end{tabular}

a $\mathrm{CH}_{2} \mathrm{Cl}_{2}-\mathrm{EtOH}-14 \% \mathrm{NH}_{4} \mathrm{OH}(4: 7: 2)$.

b $\mathrm{BuOH}-\mathrm{AcOH}-\mathrm{H}_{2} \mathrm{O}(3: 1: 2)$.

Fig. 2. IR spectrum of melanostatin (KBr).

(\%)

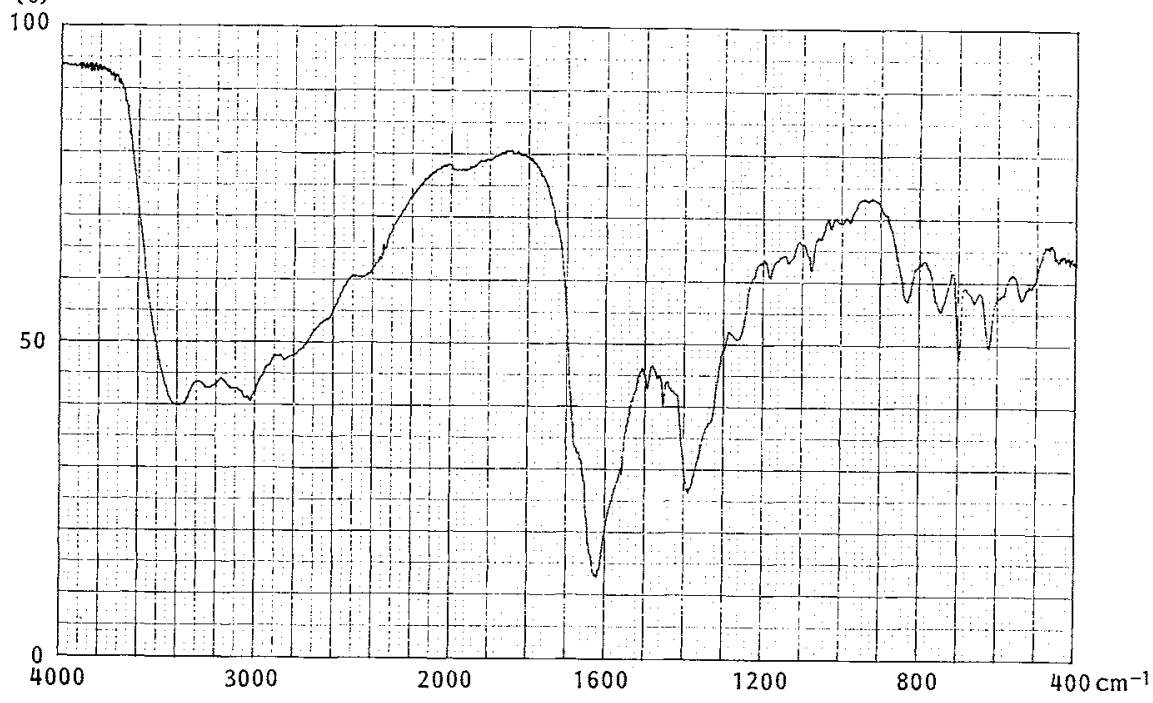


Fig. 3. ${ }^{1} \mathrm{H}$ NMR spectrum of melanostatin $\left(400 \mathrm{MHz}\right.$ in $\left.\mathrm{D}_{2} \mathrm{O}\right)$.

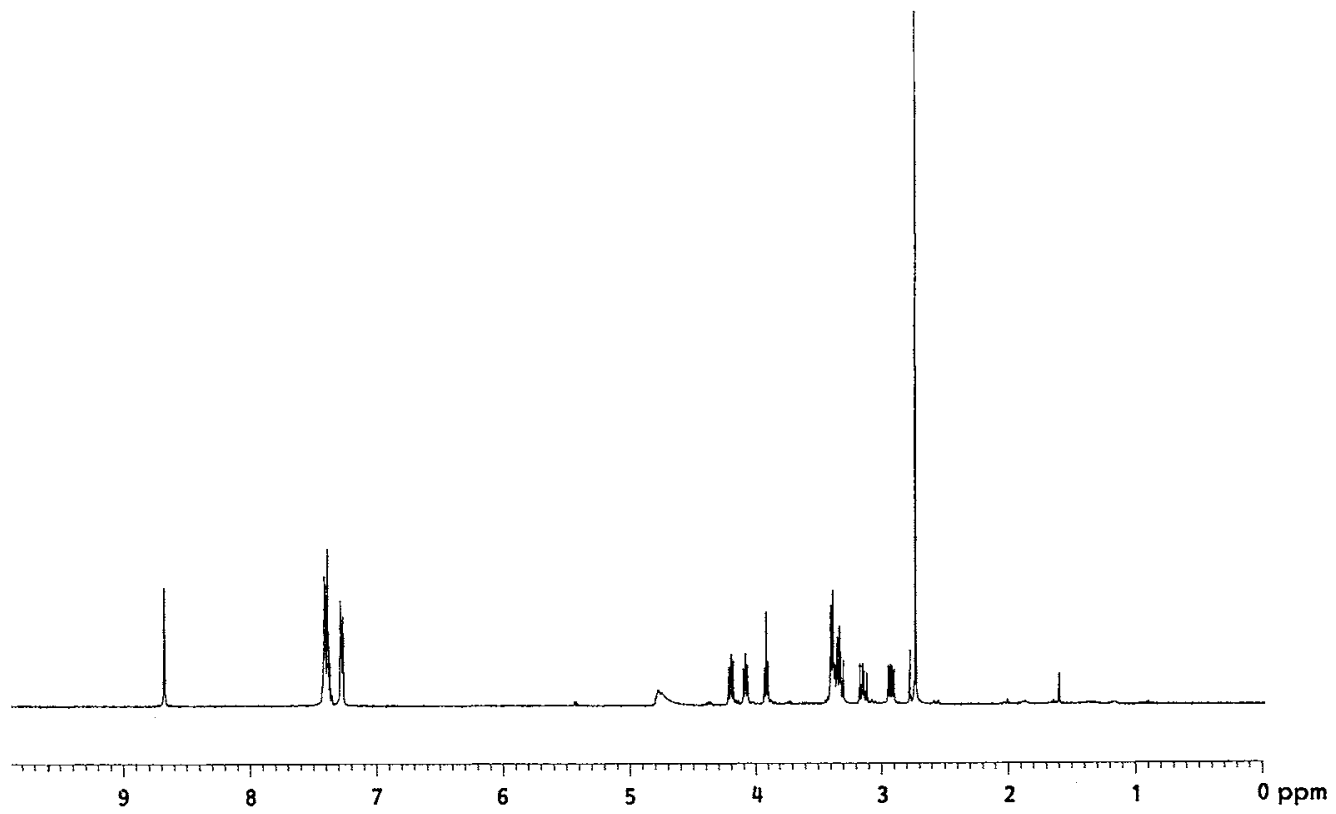

Table 3. ${ }^{1} \mathrm{H}$ NMR spectrum of melanostatin $(400 \mathrm{MHz}$ in $\mathrm{D}_{2} \mathrm{O}$ ).

\begin{tabular}{|c|c|}
\hline Chemical shift ${ }^{\mathrm{a}}$ & Interaction and assignment \\
\hline $\begin{array}{l}2.73(3 \mathrm{H}, \mathrm{s}) \\
2.92(1 \mathrm{H}, \mathrm{dd}, 6.2,12.2) \\
3.14(1 \mathrm{H}, \mathrm{dd}, 8.6,13.7)\end{array}$ & $\mathrm{CH}_{3}-\mathrm{N}$ \\
\hline $3.30(1 \mathrm{H}, \mathrm{dd}, 7.7,12.2)-$ & $-\mathrm{CH}_{2} \mathrm{CH}=\left\{\begin{array}{l}2.92,3.30 \\
4.08\end{array}\right.$ \\
\hline $3.35(1 \mathrm{H}, \mathrm{dd}, 6.4,13.7)$ & $--\mathrm{CH}_{2} \mathrm{CH}=\left\{\begin{array}{l}3.14,3.35 \\
4.20\end{array}\right.$ \\
\hline $\begin{array}{l}3.39(2 \mathrm{H}, \mathrm{d}, 6.6) \\
3.91(1 \mathrm{H}, \mathrm{t}, 6.6) \\
4.08(1 \mathrm{H}, \mathrm{dd}, 6.2,7.7) \\
4.20(1 \mathrm{H}, \mathrm{dd}, 6.4,8.6)\end{array}$ & $-\mathrm{CH}_{2} \mathrm{CH}=3.39,3.91$ \\
\hline $\begin{array}{l}7.27(2 \mathrm{H}, \mathrm{m}) \\
7.40(4 \mathrm{H}, \mathrm{m}) \\
8.67(1 \mathrm{H}, \mathrm{d}, 1.5)\end{array}$ & $\begin{array}{l}\text { Phenyl protons }(5 \mathrm{H}) \\
\text {-Imidazole protons }(2 \mathrm{H})\end{array}$ \\
\hline
\end{tabular}

a $\delta$ ppm (intergration, multiplicity, $J=\mathrm{Hz}$ ).

synthesis inhibitory activity by the $S$. bikiniensis assay system ${ }^{1}$. The molecular formula of melanostatin $\left(\mathrm{C}_{19} \mathrm{H}_{25} \mathrm{~N}_{5} \mathrm{O}_{5}\right)$ was distinctly different from those of the known antibiotics. The ${ }^{1} \mathrm{H}$ NMR in $\mathrm{D}_{2} \mathrm{O}$ exhibited 19 protons which were analyzed with the aid of the ${ }^{1} \mathrm{H}-{ }^{1} \mathrm{H}$ COSY spectrum (Table 3$)$ as one $\mathrm{N}-\mathrm{CH}_{3}$, one 4-substituted imidazole, one phenyl group and three sets of isolated $\mathrm{CH}_{2} \mathrm{CH} \leqslant$ groups. On acid hydrolysis in $6 \mathrm{~N} \mathrm{HCl}$, melanostatin $(30 \mathrm{mg}$ ) yielded two ninhydrin-positive substances (AA-1, $11.0 \mathrm{mg}$ and AA-2,6.4 mg) which were isolated by chromatography on Dowex 50X8. AA-1 was identified as $N$-methylphenylalanine based on its spectral data and comparison with an authentic sample. The L- 
configuration was assigned to AA-1 by HPLC comparison with $\mathrm{D}$ - and $\mathrm{L}-\mathrm{N}$-methylphenylalanine using a chiral column (Waters Nova Pak $\mathrm{C}_{18}$, elution: $2 \mathrm{~mm} N, N$-dipropyl-L-alanine and $1 \mathrm{~mm}$ cupric acetate in water, $\mathrm{pH} 5.0)^{10}$. AA-2 was identical in all respects with L-histidine ${ }^{11}$. Assignment of the configuration was confirmed by HPLC with a chiral column (Tosoh MFG Co., Ltd., TSK gel Enantio-L1). The ${ }^{13} \mathrm{C}$ NMR spectrum (Table 4) showed 17 (2 signals were duplicated) well-defined carbon signals which were analyzed on the basis of off-resonance decoupling, considerations of substituent effect and comparison with those of feldamycin. In the spectrum determined at $\mathrm{pH} 2.0$, significant upfield shifts $(3 \sim 9 \mathrm{ppm})$ were observed for the carbons $\beta$ to the amino functions (C-6, C-11, C-14 and C-18) in addition to carboxyl carbons (C-8 and C-12). Interpretation of these spectral data led to the complete structure for melanostatin as shown in the previous page. The absolute configuration of the diaminopropionic acid moiety (C-11) was elucidated by chemical synthesis as will be described in a later paper ${ }^{12}$.

\section{Biological Activity}

\section{Melanin Synthesis Inhibition in S. bikiniensis NRRL B-1049}

Melanin Synthesis inhibition assay in S. bikiniensis NRRL B-1049 was performed by the procedure described in the previous paper ${ }^{1}$. A spore suspension of the $S$. bikiniensis was spread over modified medium ISP No. 7 (tyrosine agar medium $+0.2 \%$ yeast extract) solidified in a plastic plate. After drying the agar surface, paper discs containing the test samples were placed on the surface and the plate was incubated at $28^{\circ} \mathrm{C}$ for 48 hours. The inhibition zone of melanin formation was measured from the back side of the plate. Inhibition zones obtained for melanostatin are shown in Table 5 along with those of four reference compounds.

\section{Inhibition of Melanin Synthesis in B16 Melanoma Cells}

Melanostatin was tested for inhibitory effect on melanin synthesis in cultured melanin-producing murine B16 melanoma cells in comparison with two related antibiotics, feldamycin and FR-900,490 and

Table 5. Inhibitory effect of melanostatin on melanin synthesis in Streptomyces bikiniensis NRRL B-1049.

\begin{tabular}{cccccc}
\hline $\begin{array}{c}\text { Concentration } \\
(\mu \mathrm{g} / \mathrm{ml})\end{array}$ & Melanostatin & Feldamycin & FR-900,490 & $\begin{array}{c}\text { 4-Hydroxy- } \\
\text { anisole }\end{array}$ & Hydroquinone \\
\hline 250 & $32^{\mathrm{a}}$ & 34 & 40 & 24 & 13 \\
125 & 30 & 30 & 38 & 18 & - \\
62.5 & 30 & 28 & 35 & - & - \\
\hline
\end{tabular}

a Inhibition zone diameter (mm).

-: No inhibition.

Table 6. Inhibitory effect of melanostatin on melanin synthesis in B16 melanoma cells.

\begin{tabular}{|c|c|c|c|c|c|c|c|c|c|}
\hline \multirow{3}{*}{ Compound } & \multicolumn{9}{|c|}{$\%$ Inhibition of melanin synthesis ${ }^{\mathbf{a}}$} \\
\hline & \multicolumn{9}{|c|}{ Concentration $(\mu \mathrm{g} / \mathrm{ml})$} \\
\hline & 50 & 25 & 12.5 & 6.3 & 3.2 & 1.6 & 0.8 & 0.4 & 0.1 \\
\hline Melanostatin & 62 & 47 & 35 & 32 & 9 & 3 & 0 & - & - \\
\hline Feldamycin & 65 & 47 & 56 & 44 & 6 & 15 & 0 & - & - \\
\hline FR-900,490 & 50 & 47 & 47 & 47 & 53 & 15 & 0 & - & - \\
\hline Hydroquinone & - & - & - & - & - & - & - & 85 & 69 \\
\hline
\end{tabular}

a The data are mean of three experiments.

--: Not determined. 
a tyrosinase inhibitor, hydroquinone. B16 cells $(3 \times$ $10^{3}$ cells $/ \mathrm{ml}, 3.6 \mathrm{ml}$ ) in EAGLE's minimum essential medium containing $10 \%$ fetal calf serum and test compounds $(0.4 \mathrm{ml})$ were incubated for 6 days at $37^{\circ} \mathrm{C}$ in a $5 \% \mathrm{CO}_{2}$ and high humidity atomosphere. During the incubation, the culture medium was renewed once with fresh medium containing the same compound solution. On completion of in-
Table 7. Inhibition of mushroom tyrosinase by melanostatin.

\begin{tabular}{lc}
\hline & $\mathrm{IC}_{50}(\mu \mathrm{g} / \mathrm{ml})$ \\
\hline Melanostating & $>200$ \\
Feldamycin & $>200$ \\
FR-900,490 & $>200$ \\
4-Hydroxyanisole & 15 \\
Hydroquinone & 1.5 \\
\hline
\end{tabular}
cubation, cells were counted and solubilized with a mixture of $1 \mathrm{~N} \mathrm{NaOH}$ and $10 \%$ DMSO $(1: 1)$. The amount of melanin synthesized was measured at $470 \mathrm{~nm}$ by a spectrophotometer. As shown in Table 6 , melanostatin and feldamycin gave similar inhibition of melanin synthesis in growing B16 melanoma cells at concentrations ranging from 6.3 to $50 \mu \mathrm{g} / \mathrm{ml}$. FR-900,490 was slightly more potent than the above two compounds in terms of minimum effective concentration. Hydroquinone showed markedly potent inhibition of melanin synthesis in B16 melanoma cells.

\section{Inhibition of Mushroom Tyrosinase}

Inhibitory activity of melanostatin and reference compounds against mushroom tyrosinase (Sigma) was determined as reported in the previous paper $^{1)}$ with the results summarized in Table 7 . Melanostatin and the structurally related antibiotics did not inhibit mushroom tyrosinase at $200 \mu \mathrm{g} / \mathrm{ml}$, while 4-hydroxyanisole and hydroquinone showed strong inhibition against the enzyme with $\mathrm{IC}_{50}$ values of 15 and $1.5 \mu \mathrm{g} / \mathrm{ml}$, respectively.

\section{Discussion}

A novel melanin synthesis inhibitor, melanostatin was isolated in our screening using $S$. bikiniensis as the indicator organism. Its structure was elucidated to be 2-[(2S)-2-methylamino-3-phenylpropionyl]amino-3-[(1S)-1-carboxy-2-(1H-imidazol-4-yl)ethyl]aminopropionic acid. Melanostatin differs from feldamycin and FR-900,490 at the $N$-terminal amino acid moiety where (L)- $N$-methylphenylalanine is present in melanostatin while (L)- $N$-methylhistidine and (L)-asparagine are present in feldamycin and FR-900,490, respectively. Furthermore, feldamycic acid, the common fragment of the feldamycin and FR-900,490 molecules was replaced by desmethylfeldamycic acid in melanostatin. Our experiment showed that feldamycin and FR-900,490 also have melanin synthesis inhibitory activity in S. bikiniensis and B16 melanoma cells ${ }^{1)}$. Feldamycin was isolated from the metabolites of $S$. ficellus as a minor antibiotic component weakly active against Gram-positive bacteria ${ }^{2)}$. FR-900,490 was reported to restore the decreased immune system in mammalian cells and to inhibit tumor metastasis ${ }^{3)}$. Melanin synthesis inhibitory activity of these types of structures has previously not been reported.

Acknowledgments

The authors thank Dr. M. KoHSAKa of the Exploratory Research Laboratories, Fujisawa Pharmaceutical Co., Ltd. for the sample of FR-900,490. They also wish to thank Prof. M. OHASH of the University of Electro-communication for mass spectral analysis and valuable discussion. They are grateful to Dr. H. KawAGUCH, the consultant for their institute for his interest and encouragement and the Analytical Group for their excellent spectral analysis.

\section{References}

1) Tomita, K.; N. Oda, M. Ohbayashi, H. Kamei, T. Miyaki \& T. OKI: A new screening method for melanin biosynthesis inhibitors using Streptomyces bikiniensis. J. Antibiotics 43: $1601 \sim 1605,1990$ 
2) Argoudelis, A. D.; S. A. Mizsak, L. Baczynskyj \& R. J. Wnuk: The structure of feldamycin. J. Antibiotics 29: $1117 \sim 1119,1976$

3) Terano, H.; Y. Tsurumi, H. Setoi, M. Hashimoto \& M. Kohsaka (Fujisawa Pharm.): Amino acid derivatives and production thereof. Jpn. Kokai 227554 ('86), Oct. 9, 1986

4) Pridham, T. G. \& H. D. Tresner: Genus I. Streptomyces Waksman and Henrici 1943. In Bergey's Manual of Determinative Bacteriology, 8th Ed., Eds., R. E. Buchanan \& N. E. Gibbons, pp. 748 829, Williams \& Wilkins Co., 1974

5) Shirling, E. B. \& D. GotTlieb: Cooperative description of type cultures of Streptomyces. II. Species descriptions from first study. Int. J. Syst. Bacteriol. 18: $69 \sim 189,1968$

6) Shirling, E. B. \& D. Gottlieb: Cooperative description of type cultures of Streptomyces. III. Additional species descriptions from first and second studies. Int. J. Syst. Bacteriol. 18: 279 392, 1968

7) Shirling, E. B. \& D. GotTlieb: Cooperative description of type cultures of Streptomyces. IV. Species descriptions from the second, third and fourth studies. Int. J. Syst. Bacteriol. 19: 391 512, 1969

8) Shirling, E. B. \& D. Gottlieb: Cooperative description of type strains of Streptomyces. V. Additional descriptions. Int. J. Syst. Bacteriol. 22: 265 394, 1972

9) Waksman, S. A. (Ed.): Description of Species of Streptomyces. The Actinomycetes. Vol. 2. Classification, Identification and Descriptions of Genera and Species. p. 197, Williams \& Wilkins Co., 1961

10) IshiwatA, A.: High-performance liquid chromatography of amino acid enantiomers by UV detection. Abstracts of Papers of 5th Symposium on Liquid Chromatography, pp. 38 39, Tokyo, Oct. 30, 1984

11) Takita, T.; Y. Muraoka, K. Maeda \& H. Umezawa: Selective cleavage of bleomycin. Proc. 8th Symp. on Peptide Chem., pp. $179 \sim 183$, Osaka, Nov. 26 27, 1970

12) Imae, K.; H. Kamachi, H. Yamashita, T. Okita, S. Okuyama, T. Tsuno, T. Yamasaki, Y. Sawada, M. Ohbayashi, T. NAITO \& T. OKI: Synthesis, stereochemistry, and biological properties of the depigmenting agents, melanostatin, feldamycin and analogs. J. Antibiotics 44: 76 85, 1991 